практику здійснення судами кримінального провадження на підставі угод». URL : https://zakon5.rada.gov.ua/laws/show/v0013740-15.

5. Тітко I. А. Нормативне забезпечення та практика реалізації приватного інтересу в кримінальному процесі України : автореф. дис. ... докт. юрид. наук : 12.00.09. Нац. юрид. акад. імені Ярослава Мудрого ; Харків, 2016. 36 с.

DOI https://doi.org/10.30525/978-9934-588-92-1-92

\title{
ОСОБЛИВОСТІ ПРАВОСУДДЯ, ДРУЖНЬОГО ДО ДИТИНИ (КРИМІНАЛЬНИЙ АСПЕКТ)
}

\author{
Хмелевська Н. В. \\ кандидат юридичних наук, \\ доиент кафедри кримінального права та проиесу \\ Хмельницького університету управління та права \\ імені Леоніда Юзькова \\ м. Хмельницький, Украӥна
}

Актуальним питанням в Україні є здійснення правосуддя за участю дитини. Найбільш складним $є$ притягнення неповнолітніх до кримінальної відповідальності. Важливим в цьому є дотримання всіх особливостей, які існують задля найшвидшого виведення дитини із конфлікту з законом.

Одним із найважливіших моментів $є$ дотримання швидкого розгляду кримінальних проваджень щодо неповнолітніх. Кожна особа (незалежно від віку) відповідно до ст. 6 Конвенції про захист прав людини і основоположних свобод має право на розгляд іiі справи протягом розумного строку. Водночас у випадку кримінального провадження щодо неповнолітнього застосуванню підлягає більш сувора вимога - невідкладний розгляд. На міжнародному рівні існує консенсус із приводу того, що для дітей, які перебувають у конфлікті із законом, період часу між вчиненням злочину й остаточним реагуванням на цей вчинок має бути якомога коротшим. Чим триваліший $є$ цей період, тим більшою $є$ ймовірність того, що захід реагування втратить свій позитивний і виховний вплив, і тим більше шкоди буде завдано репутації дитини. 3 часом неповнолітній особі все важче, а іноді й неможливо, логічно і психологічно пов'язати 
процедуру судового розгляду i винесення рішення iз самим правопорушенням» [1].

Слід погодитись, що чим довше триває судовий розгляд щодо неповнолітнього, тим більше негативного впливу зазнає дитина. Зазвичай довгий розгляд виснажує неповнолітнього, відриває від звичного життя та навчання, виховний вплив знижується.

В Україні існує проблема приміщень та спеціальних кімнат в них для проведення розслідувань та судових розглядів відносно неповнолітнього. Зазвичай слідчі дії чи судовий розгляд відбувається в тому ж приміщені, що і для дорослих. Ніхто не ознайомлює дитину 3 цими приміщеннями та не пояснює їх організацію. Слід відмітити, що позитивна тенденція існує. У деяких судах та відділках поліції $\epsilon$ «зелені» кімнати, в яких працюють 3 дітьми. Так, у Мирноградському відділенні поліції нещодавно з'явилась «зелена» кімната для дітей.

Головною метою створення $\mathrm{i}$ функціонування таких кімнат $\epsilon$ соціальний і правовий захист дітей, виявлення та документування злочинів, скоєних дітьми чи проти них. Також цей простір може бути використано для проведення заходів щодо психологічної профілактики та корекції відхилень у поведінці неповнолітніх.

Організація роботи здійснюється на основі індивідуального підходу до кожної дитини.

«Зелена кімната» представляє собою приміщення: в одному з них облаштовано ігровий зал, де 3 дитиною працюватиме психолог чи медик, інше призначено для спостереження, де перебуватимуть слідчий та інші працівники поліції. Завдяки спеціальним методикам роботи та комфортним умовам мінімізується стрес та переживання дитини під час перебування в поліції [2].

Для забезпечення гуманного процесу правосуддя у питаннях щодо дітей, які потрапили у конфлікт із законом чи перебувають у контакті із законом, у всіх категоріях судових справ в Луцькому міськрайонному суді Волинської області обладнано дитячу («зелену») кімнату.

Спеціально обладнана дитяча кімната дозволяє при проведенні суддею опитування вберегти дитину від складних випробувань в ході судових процедур, запобігти травматизації психіки дитини за допомогою спеціальних дружніх до дитини методик та створення психологічно комфортної атмосфери. Дитяча «зелена» кімната допомагає дітям відчути домашню атмосферу, сприяє довірливому спілкуванню з дорослими.

Кімната обладнана м'якими меблями, іграшками та книгами для різних вікових груп дітей, дошкою для малювання, дитячим навчальним приладдям. Тут $є$ всі речі, необхідні для опитування дитини, зокрема, анатомічні ляльки, малюнки, тести, опитувальники. 
Кімната забезпечує дитині почуття безпеки та конфіденційності й відповідає потребам дітей почуватися у фізичній та психологічній безпеці під час опитування, розслабитися і відчути довіру до судді.

Організація роботи в дитячій («зеленій») кімнаті здійснюється суддею на основі індивідуального підходу до кожної дитини 3 урахуванням iї вікових та психофізіологічних особливостей. Для роботи 3 дітьми можуть запрошуватися відповідні фахівці - психологи або педагоги.

Дитяча («зелена») кімната допомагає дітям відчути затишну, доброзичливу атмосферу, сприяє відкритому/довірливому спілкуванню/діалогу з дорослими. Як засвідчує досвід, діти в таких кімнатах краще ідуть на контакт [3].

Вказані кімнати є ще у декількох судах України. Вважаю, що у кожному суді необхідно облаштувати «зелену» кімнату, щоб забезпечити правосуддя, дружнє до дитини.

Ще слід звернути увагу на право на захист неповнолітнього, якого притягують до кримінальної відповідальності. У КПК України визначено обов'язкову участь захисника у кримінальному провадженні щодо осіб, які підозрюються або обвинувачуються у вчиненні кримінального правопорушення у віці до 18 років. В цілому не порушуть права на захист неповнолітніх, проте трапляються виключення. Так, $є$ рішення Касаційного кримінального суду у складі Верховного Суду, у яких констатовано порушення права на захист. Зокрема, проведення слідчої дії (огляду місця події, пред’явлення для впізнання) за участю неповнолітнього без залучення його законного представника або захисника. Оцінюючи як доказ протокол огляду місця події суд врахував, що під час проведення слідчої дії за участю неповнолітнього були відсутні як законний представник, так і захисник, участь якого у цьому кримінальному провадженні $\epsilon$ обов'язковою 3 моменту встановлення факту неповноліття або виникнення будь-яких сумнівів у тому, що особа $\epsilon$ повнолітньою, як це встановлено вимогами п. 1 ч. 2 ст. 52 Кримінальний процесуальний кодекс України. 3 огляду на таке порушення права на захист неповнолітнього суд дійшов висновку, що доказ був отриманий внаслідок порушення його прав i свобод, а тому використання фактичних даних, отриманих під час такої слідчої дії, суд обгрунтовано визнав неприпустимим.

Ще одним порушенням визнано розгляд справи в апеляційному порядку за відсутності засудженого, який на час скоєння злочину був неповнолітньою особою, та його захисника. Так, кримінальне провадження щодо неповнолітніх здійснюється у загальному порядку з урахуванням особливостей, передбачених главою 38 КПК, та 3 дотриманням принципу забезпечення реалізації неповнолітніми 370 
особами права користуватися додатковими гарантіями, встановленими вітчизняним законом i міжнародними договорами, згода на обов'язковість яких надана Верховною Радою України. Якщо норми КПК суперечать такому міжнародному договору, згідно із ч. 4 ст. 9 КПК застосуванню підлягають положення відповідного договору. При цьому неповнолітньому підозрюваному (обвинуваченому) має бути реально забезпечено його право на захист, у тому числі шляхом забезпечення обов'язкової участі захисника в судовому провадженні під час розгляду кримінального провадження щодо нього, а також перегляду судових рішень за результатами судового розгляду в судах усіх інстанцій незалежно від стадії судового провадження та суб'єкта оскарження. Пунктом «с» ст. 6 Конвенції про захист права людини i основоположних свобод передбачено право кожного захищати себе особисто чи використовувати юридичну допомогу захисника, обраного на власний розсуд. Крім того, право за захист закріплено у ст. 59 і п. 6 ст. 129 Конституції України. Як убачається з матеріалів провадження, засуджений на час скоєння злочину був неповнолітньою особою, а норми ст. 52 КПК вказують, що обов'язкова участь захисника. Таким чином, розглянувши справу в апеляційному порядку без участі засудженого та його захисника, суд не дотримався одного $з$ основних принципів судочинства - права на захист [4].

Отже, розглянуті деякі особливості правосуддя, дружнього до дитини у кримінальному провадженні.

\section{Література:}

1. Особливості здійснення кримінальних проваджень щодо неповнлітніх. Навчально-методичний посібник. Київ. 2017. URL: http://www.nsj.gov.ua/files

2. Поліція Донеччини. Офіційний сайт. URL: http://police.dn.ua/news/view/u-mirnogradskomu-viddilenni-politsiizyavilasya-zelena-kimnata-dlya-ditej

3. Судова влад України. Луцький міськрайонний суд Волинської області. URL: https://kv.vl.court.gov.ua/sud0308/pres-centr/news/421381

4. Огляд судової практики Касаційного кримінального суду у складі Верховного Суду щодо забезпечення права на захист у кримінальних провадженнях (справах). Рішення, внесені до ЄДРСР за період 3 15.01.2018 по 01.06.2019. URL: https://supreme.court.gov.ua/ userfiles/media/Oglyad_KKS_2.pdf 